\title{
Parliamentary representation: Should MPs prioritise their own views or those of their voters?
}

\author{
Siim Trumm (University of Nottingham) \\ Andrew Barclay (University of Sheffield)
}

Journal: Political Studies

Date of acceptance: $31 / 10 / 2021$

\begin{abstract}
The 2016 European Union referendum revealed fundamental divisions in British politics and society more broadly. It also raised key questions around representation and the role of Members of Parliament. Should they follow their own judgement or their constituents' preferences when the two are not aligned? This study uses data from the Representative Audit of Britain Survey to examine what parliamentary candidates believe the answer to this question should be. We find that most candidates expect Members of Parliament to prioritise their own views. This belief is particularly prevalent among incumbents and those who do not think of Members of Parliament as career politicians. We also find a gender effect as male candidates are more likely to think that Members of Parliament should prioritise their own views than female candidates. Interestingly, however, there is no evidence of a Brexit effect when we compare the views of 2015 and 2017 general election candidates.
\end{abstract}

Keywords: representation, political elites, role perception, voting, Britain 


\section{Introduction}

The 2016 European Union (EU) referendum exposed major divisions in British politics and society. Among the most notable of these has been the perceived disconnect between the preferences of voters and politicians. It is widely noted that politicians were much less likely to vote for Brexit than voters, but, more than that, a 'parliament versus people' narrative emerged whereby political elites were seen to obstruct the United Kingdom's (UK's) exit from the EU against the will of the public (Russell 2019). Even years after the EU referendum, sentiments such as politicians not caring what people think remain prevalent, while trust in Members of Parliament (MPs) and in the UK Government doing the right thing very low (Fieldhouse et al. 2020). The scepticism that many voters view politicians with has raised the fundamental question of whether elected representatives ought to prioritise their own judgement or the preferences of their voters when the two are not aligned?

There is a growing body of literature examining questions around parliamentary representation. These studies consistently show that voters prefer their elected representatives to directly reflect the views of their constituents in the legislative process (e.g., Campbell et al. 2019; Carman 2006; McKay 2020), and we have a good understanding of how politicians carry out their duties from analyses of roll call data and parliamentary questions (e.g., Adler 2018; Kolpinskaya 2017; Saalfeld 2011). We also have emerging insights from cross-national studies about how politicians tend to perceive the role of MPs (e.g., Deschouwer and Depauw 2014; Dudzińska et al. 2014; Sudulich et al. 2020). However, these do not focus explicitly on the dilemma between MPs' views and their voters' views, and only look at a limited set of individual-level factors. Moreover, we still lack a detailed understanding of whether the EU referendum, which brought not only the disconnect between MPs' and voters' views into new-found prominence, but also led to extensive news coverage of MPs' subsequent voting choices in the House of Commons and whether they followed 'the will of their constituents', ${ }^{1}$ has influenced politicians to re-evaluate how they believe MPs ought to vote when facing a dilemma between following their own views or those of their voters.

Our study uses survey data from the Representative Audit of Britain Survey to address this lacuna. We focus on candidates who stood at the 2015 and 2017 general elections in Britain and examine how they believe MPs ought to approach parliamentary representation, as well as what explains variation in their views. In doing so, this article not only extends our understanding of how would-be MPs perceive the role of legislators, but it also contributes to debates about the impact (or lack thereof) that the EU referendum has had on how politicians believe the relationship between MPs and their constituents

\footnotetext{
${ }^{1}$ The news headlines included 'The Brexit Wreckers: MPs who are betraying their constituents by trying to thwart Brexit' (The Sun 2019), 'The Remoaners-in-chief: MPs who defied the will of their constituents by voting against triggering Article 50' (Daily Mail 2017), and 'More than 120 MPs voted against their Constituencies on Brexit' (Buzzfeed 2017), among others, with the stories often highlighting the 'rebel' MPs by name.
} 
ought to work. The analysis reveals some interesting patterns. We find that most candidates, by a ratio of around 2:1, expect MPs to prioritise their own judgement over the views of their voters when these are in conflict. We also find that both candidates' personal and political traits influence how they see the role of MPs. It is incumbents and those who do not think of MPs as career politicians who are particularly likely to believe that MPs ought to prioritise their own judgement, while men are also more likely to think that than women. Interestingly, however, we find no meaningful Brexit effect when comparing the views of 2015 and 2017 general election candidates. These findings touch upon some of the key debates and perceptions in British politics, offering further insight into how politicians see the role of MPs, as well as providing support for the idea that politicians and voters differ in how they want MPs to behave.

The article is organised as follows. In the next sections, we discuss the importance of the topic and the relevant literature. We then outline our theoretical expectations, describe the data, the operationalisation of variables, and the empirical strategy. This is followed by the presentation of the empirical findings, and we conclude with a brief discussion of their broader implications.

\section{Political disconnect}

The 2016 EU referendum was a highly divisive event. One of the most notable divisions it exposed was the perceived disconnect between voters and elected representatives. Whereas the majority of voters cast their ballot for Leave, most MPs in the 2015-2017 Parliament, by a ratio of around 3:1, voted for Remain instead (Press Association 2016). This pattern was just as clear locally where most Labour and Conservative MPs voted differently to the majority of their constituents (Stafford 2020). The magnitude and salience of these divisions, together with the following parliamentary impasse over the Brexit terms, brought the question of whether MPs should prioritise their own views or those of their constituents to the forefront of the public discourse.

This question of representation is particularly pertinent given the broader political context. On the one hand, we live in an era where concerns around political trust and the democratic process have become highly salient. Trust in political elites in Britain is low and declining (Clarke et al. 2018), with polling data suggesting that only $14 \%$ of voters trust MPs to tell the truth (Ipsos Mori 2019). Moreover, many voters no longer believe that politicians care about what ordinary people think (Fieldhouse et al. 2020) and even levels of democratic satisfaction are decreasing (Jennings et al. 2020). These sentiments are not unique to Britain, but they nonetheless point towards growing public disquiet about politicians and politics more broadly. On the other hand, politicians are increasingly willing to not 'toe the party line' on big issues. While it is true that the Westminster system has tended to produce strong party cohesion and discipline (Campbell and Cowley 2014; Slapin et al. 2018), British MPs seem to have become more rebellious over time, as we saw with Tony Blair's welfare reforms or David Cameron's introduction of 
same-sex marriage (e.g., Cowley 2002; Cowley and Stuart 2010; Heppell et al. 2017). It has also been shown that MPs representing socially conservative constituencies tend to vote along their constituents' views (Baughman 2004). While the lack of party discipline in the EU referendum, and the subsequent parliamentary divisions over the terms of leaving, is not a typical feature of the British political system, it is becoming less uncommon for issues to arise where MPs look beyond party whips when deciding how to vote.

Under these circumstances, the way would-be MPs perceive the role of a parliamentarian is neither an abstract nor a peripheral concern. Whether they believe MPs ought to prioritise their own judgment or the preferences of their voters, when these are not aligned, may have real-life practical implications in the context of policy outcomes, but it also touches upon one of the most prominent questions in public discourse about the relationship between voters and their elected representatives.

\section{Competing incentives}

There is an extensive body of literature already that focuses on the conceptualisation of representation (e.g., Andeweg and Thomassen 2005; Converse and Pierce 1986; Searing 1994). However, despite the richness of this literature, there is broad agreement about the existence of three ideal types of priorities for elected representatives: party line, own judgment, and voters' preferences. In this article, we focus on the interplay between the last two as it is the question of whether MPs ought to prioritise their own views or those of their constituents that the EU referendum put to the forefront of public discourse.

Candidates have good reasons to adopt the position that MPs should prioritise the preferences of their voters over their own views. After all, this is exactly what voters want MPs to do. Research has shown that voters prefer their representatives to focus on local, rather than national, concerns (e.g., Campbell and Lovenduski 2015; Doherty 2013) and be 'listeners' not 'leaders' (Barker and Carman 2012). This pattern was present in the early 2000s (Carman 2006) and is also there in the recent British Election Study data (Fieldhouse et al. 2020). It does appear that voters want their elected representatives to act in local interest and prioritise the preferences of their constituents. Moreover, doing so contributes to higher levels of political trust (McKay 2020), which is particularly important at the present time when levels of trust towards politicians and politics are low in Britain and beyond. Taken together, there are normative and practical incentives for candidates to take the view that MPs should prioritise the views of their voters.

At the same time, candidates also have incentives to want to view MPs as independent-minded actors who prioritise their own views. To start off with, this is not an abstract issue for candidates as they are actively trying to become MPs. It would be reasonable to expect that, if they get elected, they would like to act in accordance with their own best judgement, rather than follow the views of someone else. 
Therefore, there is likely to be a degree of personal desire for them to have the role of MPs be seen in independent-minded terms. Moreover, the electoral consequences of discarding voters' views, in favour of one's own judgement, tend to be limited. It is true that many voters were acutely aware of how their MP voted at the EU referendum and whether it matched the constituency's position, and that websites like www.theyworkforyou.com and www.publicwhip.org.uk make it easier for voters to scrutinise MPs' voting record, but general levels of political knowledge and awareness in Britain remain relatively low (Fieldhouse et al. 2020). It is reasonable to expect that the potential cost for discarding voters' views, in favour of one's own judgement, is usually low for MPs. In fact, Wagner et al. (2020) reveal that MPs who disagree publicly with their party receive a bonus in voter evaluations. Admittedly, it is likely that any bonus is smaller when the dissent entails going against voters' views, but it still signals character valence. There are good reasons for candidates to suggest that MPs ought to prioritise the views of their voters as well as those of their own when the two are not aligned.

We already have a good understanding of how voters expect MPs to respond when facing this voting dilemma. Studies of the supply side, however, have taken a predominantly behavioural approach by focusing on roll call data and parliamentary questions (e.g., Adler 2018; Kolpinskaya 2017; Saalfeld 2011). While it is important to explore MPs' parliamentary behaviour, representation goes above and beyond parliamentary debates and votes. It is determined by how those who are, or seek to be, elected representatives understand its meaning. There is of course a growing number of studies exploring how politicians believe MPs should approach parliamentary representation (e.g., Deschouwer and Depauw 2014; Dudzińska et al. 2014; Sudulich et al. 2020), but they focus on a limited number of individuallevel factors. For example, we still know little about how political attitudes regarding politicians and the broader political system shape views on representation. Moreover, the existing studies tend to rely on survey data from the pre-referendum period, meaning that they are unable to account for the potential influence that the EU referendum may have had in shaping how politicians think about the role of MPs.

\section{Potential differences in role perception}

Individual-level characteristics and political context are both likely to influence candidates' views on how MPs should approach parliamentary representation. We distinguish between four distinct types of factors that we have reasons to believe might shape attitudes towards representation. First, it is highly likely that candidates' political and personal profile matters. Those who have experienced working in a parliamentary setting, as an MP or MP's assistant, are more likely to value the agency of MPs. This is due to their socialisation into Westminster politics, which should contribute to greater appreciation of the expertise and public service values that MPs hold. Moreover, the experience that those candidates have attained through being part of parliamentary decision-making ought to lead to greater confidence in their own agency and more likely to consider MPs as independent-minded actors (Hafner-Burton et al. 2013). The effect of such socialisation is likely to be stronger for an MP than an MP assistant as the 
former are the ones who have experienced first-hand the variety of tensions and dilemmas encountered by MPs when voting in the House of Commons, but the latter, nonetheless, have 'second hand' exposure to these through their proximity to and close relationship with the MP they are working for. In addition, research in political psychology finds that men are often more confident in developing and arguing for their views than women (e.g., Albarracín et al. 2012; Kalaian and Freeman 1994; Lausberg 2016), which implies that male candidates might be more inclined to see the role of MPs in independent-minded terms than their female counterparts.

We also expect candidates' attitudes towards the political system to shape their views on how elected representatives should behave. It is likely that candidates, like voters, vary in the extent to which they hold positive (or negative) views about the 'political class' and the state of British politics more broadly. For example, it is well-established that populist parties, and their candidates, often advocate for direct forms of democratic governance that allow ordinary people to make policy and hold anti-establishment views. $^{2}$ It is reasonable to expect that those candidates who hold British democracy and its 'political class' in poor esteem are naturally more inclined to side with voters in the 'people versus politicians' dichotomy. Therefore, they ought to be more likely to wish MPs to prioritise their voters' preferences over their own views.

Next, candidates' relationship with their constituents should matter. On the one hand, candidates who live in the community they seek to represent are likely to be more invested in local matters By virtue of living locally, they are also more likely to interact with businesses, schools, universities, etc. in their constituency, and form personal bonds and friendships with their constituents. It is reasonable to expect that these interactions lead to greater levels of trust in voters' judgements, ${ }^{3}$ which could, by extension, manifest in a stronger belief that MPs should prioritise the views of their constituents. On the other hand, the EU referendum may have influenced how politicians think about representation. It is quite plausible that would-be MPs who found themselves in agreement with their constituents on what was one of the most important political issues of our times gained further confidence in their own judgement, while those who found themselves in disagreement may be more hesitant to suggest that MPs ought to discard the views of their constituents in order to follow those of their own.

\footnotetext{
${ }^{2}$ In the context of Britain and parties focused on in this paper, it is the UK Independence Party (Ukip) that stands out in terms of its populist appeal. The party consistently pledges policies that advocate direct democracy like the proposal in both their 2015 and 2017 manifestos to hold a national referendum every two years on the most popular petitions (BBC 2015, 2017) and uses complete-populist rhetoric - i.e., appeals to ordinary people, language related to othering, and anti-elite discourse - when reaching out to voters (Hughes 2019; Stanyer et al. 2017). While this is not to say that other parties have not utilised populist appeals (Watts and Bale 2019), these are not as central to their communication and campaign strategies as they are for Ukip. After all, it is more difficult for parties that are - or have recently been - in power to portray themselves as outsiders standing up against the 'political elite', just like it would be less natural for parties that are more liberal in their outlook to utilise othering tropes.

${ }^{3}$ Research into the distribution of social and political trust shows that people are most likely to trust those whom they know best (Zmerli and Newton 2017).
} 
Finally, we expect to find a Brexit effect in how candidates consider the role of MPs. The themes that dominated the public discourse in the aftermath of the EU referendum included the perception that the 'political class' is acting against the will of the British people and that MPs should represent the views of their constituents (Vasilopoulou 2020). While academic studies have long concluded that there is an expectation among voters that MPs should follow local preferences (Campbell et al. 2019), this became even more publicised after the referendum. It is likely that the strength of this sentiment may have encouraged some politicians who, prior to the referendum, expected MPs to prioritise their own opinion over that of their voters to re-consider and change their mind.

We have summarised our expectations in Table 1, listing the hypotheses and the corresponding effects as we expect these in the empirical models. Both are expressed in relations to candidates seeing MPs as politicians who should prioritise the preferences of their voters over their own judgment.

\section{[TABLE 1 HERE]}

\section{Data and methods}

The analyses are based on individual-level survey data collected as part of the Representative Audit of Britain Survey about candidates who stood at the 2015 and 2017 general elections in Britain (Campbell et al. 2017). These surveys include questions, among else, about candidates' personal background, their political experience, and political attitudes. Taken together, they provide valuable insight into the profile and mind-set of those who seek to represent us.

There are 642 candidates in 2015 (20\% response rate) and 500 candidates in 2017 (18\% response rate) who answered all questions relevant to this study and are included in the multivariate analyses. ${ }^{4}$ These samples are broadly representative of the full population of candidates who stood at these two elections with regards to partisanship, nation, as well as electoral performance. Further details about the samples are reported in Appendix A.

There are key advantages in using these data to study candidates' views on parliamentary representation. The Representative Audit of Britain Survey is the most comprehensive survey of British would-be MPs, including questions on their personal background, political experience, and, crucially, a broad range of political attitudes. This allows us to evaluate and compare the role that different types of factors play in shaping whether candidates believe MPs should prioritise their constituents' views or those of their own

\footnotetext{
${ }^{4}$ For the purposes of calculating the response rate, the population of candidates includes only those who ran for parties and nations covered in this study.
} 
in case these are in conflict. Also, it uses a core questionnaire. The overlap in questions allows us to compare how 2015 and 2017 general election candidates view the role of MPs and explore the presence (or lack therefore) of a Brexit effect. However, it is also important to note that the reliance on survey data calls for some caution. Treating responses confidentially aims for candidates to feel able to voice their sincere, unbiased views, but it is of course possible that not all candidates do. Also, while the samples are broadly representative of the populations of candidates, there are some differences as one would expect from data derived from elite surveys (see Appendix A), meaning that one does need to apply some caution when generalising from the findings.

\section{Dependent variable}

The dependent variable in this study is priority. It is a dichotomous measure that captures whether the candidate believes MPs ought to vote according to their own opinion (coded 0) or their voters' opinion (coded 1) when the two are not aligned. ${ }^{5}$

Table 2 shows the breakdown of candidates based on how they expect MPs to behave. It presents the percentage of candidates who believe that MPs should vote according to their own opinion rather than the opinion of their voters, and vice versa, when these are not aligned. The aggregate pattern indicates that candidates are more likely to expect MPs to prioritise their own judgment than the preferences of their voters, at a ratio of approximately $2: 1 ; 66.2 \%$ versus $33.8 \% .^{6}$ There is clearly a dominant view of how MPs should behave among `candidates. The presence of a significant minority, however, suggests that the debate around the role of MPs is still an open one, even among politicians.

Table 2 also provides this breakdown by year and party. Interestingly, the initial narrative that appears to be emerging is one of consistency. The views of 2017 general election candidates are very similar to those of 2015 general election candidates. They are both more likely to say that MPs ought to prioritise their own views than those of their voters $-66.7 \%$ versus 33.3\% for 2017 general election candidates and $65.8 \%$ versus $34.2 \%$ for 2015 general election candidates - and the change in the extent to which

\footnotetext{
${ }^{5}$ The dependent variable is based on the survey question that was phrased as follows: 'How should an MP vote if his/her own opinion on an issue does not correspond with the opinion of the voters in his/her constituency?'. The question required candidates to pick between two discreet response options: 'MP should vote according to his/her own opinions' and 'MP should vote according to the opinion of the voters in his/her constituency'.

${ }^{6}$ The dominant perception among parliamentary candidates in Britain that MPs should prioritise their judgement over the preference of their voters follows closely what candidates outside Britain believe. The data from the most recent Comparative Candidates Survey (2020) - covering eighteen countries and twenty-two elections from 2013 to 2017 where the same question was asked as part of the survey - shows, on aggregate, that $64.2 \%$ of candidates expect MPs to vote according to their own opinion and 35.8\% expect MPs to vote according to voters' preferences. There is of course variation across countries, with candidates in Germany being the most likely ones to want MPs to prioritise their own judgements over their voters' opinions (81.9\% versus $18.1 \%)$ and candidates in Montenegro being the least likely ones to do that $(30.7 \%$ versus $69.3 \%)$-, but the overall pattern of how candidates in Britain perceive parliamentary representation in terms of MPs prioritising their own opinion or that of their voters is very similar to how candidates outside Britain tend to perceive it.
} 
this is the dominant view is marginal. Comparing candidates' views by partisanship does reveal larger differences, but even here they remain relatively minor. Ukip is the only party whose candidates are less likely to believe that MPs should prioritise their own views over those of their voters (39.8\% versus $60.2 \%)$. The clear majority of other parties' candidates believe that MPs should follow their own views rather than those of their voters. This percentage is lowest, excluding Ukip, for the Green Party at $61 \%$ and highest for the Conservative Party at $78.7 \%$. This does not of course mean that election year and partisanship are necessarily irrelevant to understanding how candidates think about the role of MPs, but it does suggest that other factors might have greater role in explaining variation in candidates' views on the issue.

\section{[TABLE 2 HERE]}

\section{Key explanatory variables and controls}

To shed further light on what explains holding contrasting visions of this key aspect of parliamentary representation, we capture a range of different explanatory factors.

First, we account for candidates' political and personal profile. We focus on how experiences of being an MP and working for an MP have shaped their perception of whether legislators should prioritise their own views or those of their constituents. It is plausible that such political experiences and the associated socialisation processes may have a bearing on how candidates see the role of elected representatives. Incumbency captures whether a candidate was an incumbent MP (coded 1) or a challenger (coded 0), whereas MP assistant separates candidates who have worked for an MP (coded 1) from those who have not (coded 0 ). In addition, a demographic indicator of candidates' personal profile - gender - is included in the analysis to examine whether the insight from political psychology research that men are more comfortable defending their views also holds here. It is operationalised as a dichotomous measure, with male candidates coded 1 and female candidates coded 2. Taken together, we expect incumbency and experience working as MP assistant to be negatively linked to candidates' likelihood of expecting MPs to prioritise voters' opinions over their own judgement, and male candidates to also be less likely to expect MPs to prioritise voters' opinions over their own than female candidates.

Second, we utilise three factors that account for candidates' political views. They describe candidates' perception of MPs, the role of the Parliament in the representation process, as well as their evaluation of the state of democracy in the UK. Taken together, these views touch upon the actors in the heart of parliamentary representation, the institution that carries it out, and the overall system that it is taking place within. Perception of MPs describes the extent to which candidates agree with the sentiment that the Parliament is full of political advisors and communication experts without any real-life experience, ranging from 1 'strongly disagree' to 5 'strongly agree'. Next, final decision captures how strongly 
candidates believe it is the Parliament, not voters, who should make final decisions on law and policy, ranging from 1 'strongly disagree' to 5 'strongly agree'. Finally, satisfaction with democracy describes how satisfied candidates are with the way democracy works in the UK. It ranges from 1 'not at all satisfied' to 4 'very satisfied'. In line with the expectations set out earlier, candidates should be more inclined to suggest that MPs ought to prioritise the views of their voters if they think negatively of MPs, do not agree that the Parliament should have the final say on passing legislation, and are not satisfied with the state of democracy in the UK.

Third, candidates' relationship with their constituents is captured through two indicators. Locality is a dichotomous measure that distinguishes between candidates who live in the constituency they stand for election (coded 1) and those who do not (coded 0). It is plausible that the experience of being part of the community one seeks to represent creates stronger ties with the said community which, in turn, leads to a stronger belief that MPs should trust and follow the collective wisdom of their constituents. Moving on, EU alignment captures whether candidates' EU referendum vote choice aligned with that of the majority of their constituents (coded 1 ) or not (coded 0$).{ }^{7}$ It is the perceived disconnect between voters and politicians in terms of how they voted at the EU referendum, and the subsequent vote choices of the latter in the House of Commons, that have brought the discussion around what the role of MPs ought to be - and, in particular, whether they should prioritise their own views or the views of their voters to the forefront of public attention. The experience of finding oneself in agreement or disagreement with the voters one seeks to represent is likely to influence how candidates think MPs should approach parliamentary representation. We expect both locality and EU alignment to have positive effects on the likelihood of candidates to expect MPs to prioritise their voters' opinions over their own judgement.

The empirical analysis also distinguishes between views held before and after the $2016 \mathrm{EU}$ referendum. Year identifies whether the survey response is from 2015 (coded 0) or 2017 (coded 1). ${ }^{8}$ As highlighted earlier, we expect the 2017 general elections candidates to be more likely to believe that MPs ought to prioritise voters' views than their 2015 counterparts. Finally, we control for party, separating candidates who ran under the labels of the Conservative Party (coded 1), the Labour Party (coded 2), the Liberal Democrats (coded 3), the Green Party (coded 4), Ukip (coded 5), and the SNP or Plaid Cymru (coded $6)$.

\section{Empirical strategy}

\footnotetext{
${ }^{7}$ We use estimates from Hanretty (2017) to identify the referendum position of each constituency.

${ }^{8}$ Estimates from models that are limited to 2015 general election candidates and 2017 general election candidates are presented in Appendix B.
} 
Given the dichotomous nature of the dependent variable, we use logistic regression to explore the effects of the explanatory variables on whether candidates believe MPs ought to prioritise the views of their constituents or those of their own.

\section{Findings}

We now turn to the empirical analysis to examine the effects of explanatory variables on how candidates believe MPs should vote when their own views conflict with those of their voters. Table 3 presents the findings from the logistic regression model.

Note first that candidates' views on how MPs ought to approach representation are not shaped by any one factor or type of factors, but by several factors, including elements of their political profile, personal profile, and political views. The motivations for seeing MPs as politicians who should prioritise their own views over those of their voters, or vice versa, are diverse and include different types of drivers.

Moving on, the evidence regarding the effect that candidates' political experience has on whether they believe that MPs should prioritise their own views or those of their voters suggests that it does matter. The negative and significant effect of -0.94 for incumbency suggests that incumbents are less likely to believe that MPs should prioritise the views of their voters than challengers. It lends support to the expectation that candidates who have been subject to the political socialisation that comes from being an MP are more likely to have trust in MPs' ability to develop views that would best serve the interests of their constituents. Interestingly, while the effect for MP assistant is in the same direction, it does not reach conventional levels of statistical significance. It transpires that working for an MP does not lead to political socialisation of the same intensity as being an MP. It is the latter that stands out as the key aspect of candidates' political profile that influences how they perceive parliamentary representation.

In terms of candidates' personal profile, we find a significant effect for gender. The positive coefficient of 0.86 for gender suggests that female candidates are more likely to think that MPs ought to prioritise the preferences of their voters over those of their own. In line with theoretical expectations and existing evidence (Sudulich et al. 2020), male candidates are indeed more likely to think that MPs ought to be independent-minded politicians, rather than respond to an external authority, than female candidates.

Next, candidates' political views influence whether they expect MPs to vote according to the views of their voters or those of their own. The positive coefficient of 0.22 for perception of MPs shows that candidates who think of MPs as politicians without any real-life experience are more likely to believe that MPs ought to prioritise voters' views over those of their own. The same holds for candidates who are less likely to think that Parliament, not voters, should make final decisions on law and candidates who are more satisfied with the state of democracy in the UK, as indicated by the negative coefficient 
of -0.36 and the positive coefficient of 0.21 , respectively. These effects are in line with the theoretical expectations set out earlier and, unsurprisingly, suggest that candidates' views about the actors in the heart of representation, the institution that carries it out, and the overall system that it is taking place within all shape their understanding of how MPs should vote when faced with competing preferences.

Candidates' relationship with their constituents, however, does not appear to have a systematic effect on their perception of parliamentary representation. Contrary to the expectations, the coefficients that are associated with locality and EU alignment, while in the expected direction, fail to reach conventional levels of statistical significance. We do not find sufficient evidence here that candidates who live in the constituency they seek to represent are more likely to believe that MPs should prioritise the views of their voters over those of their own than candidates who live elsewhere, nor that candidates whose EU referendum vote choice aligned with that of the majority in the constituency they stand for election in are more likely to believe that MPs should prioritise the views of their voters than candidates who did not share the same EU referendum stance than the majority of their electors.

Finally, the regression findings reaffirm what the descriptive insights suggested. We find no meaningful evidence that election year and partisanship shape how candidates believe MPs should vote when they need to balance competing preferences. The coefficient for year is positive as expected, but it does not reach conventional levels of statistical significance. This further supports the idea that there was no immediate Brexit effect in terms of how politicians perceive parliamentary representation. Moving on, partisanship is also largely irrelevant to explaining variation in candidates' views. The only significant comparison is between candidates who run under the Conservative Party and Ukip labels. The positive coefficient of 1.18 indicates that Ukip candidates are more likely to expect MPs to prioritise their voters' views over those of their own than the Conservative Party candidates.

\section{[TABLE 3 HERE]}

Given the binary nature of the dependent variable, the interpretation of effect sizes associated with the different explanatory variables is not intuitive. Therefore, Table 4 presents the predicted probabilities for candidates' likelihood of seeing MPs as politicians who should prioritise the views of their voters over those of their own. For each effect, the characteristic in question is allowed to vary, while others are held constant.

It is evident that the effects associated with all five characteristics which coefficients were statistically significant are also of meaningful size. While the strongest effect - for final decision - shows a 30.5\% difference in the likelihood of different candidates to expect MPs to prioritise their voters' views over 
those of their own, even the smallest effect size with no overlap in the $95 \%$ confidence intervals - for perception of MPs - stands at a notable $14.2 \%$.

In terms of candidates' political and personal profile, the effect sizes associated with incumbency and gender are almost identical. We find the predicted likelihood of challengers to expect MPs to prioritise their voters' views to be $15.5 \%$ higher than it is for incumbents ( $34.3 \%$ versus $18.8 \%$ ). The effect is $17.4 \%$ for gender as female candidates are more likely to believe that MPs should prioritise voters' views than their male counterparts (46\% versus $28.6 \%$ ). These predicted probabilities offer a further indication that candidates are more likely to think about parliamentary representation as a process that prioritises MPs' views over those of their voters, but they also reveal that the strength of this belief varies across candidates with contrasting political experiences and personal profile.

Moving on, two of the three aspects of candidates' political views carry meaningful effects, with the standout one being final decision. Whether candidates believe that the ultimate legislative authority should rest with the Parliament or voters has, in fact, the strongest effect of all explanatory factors covered in the analysis. The predicted likelihood of believing that MPs should prioritise their voters' views over their own is $30.5 \%$ higher for candidates who think that the ultimate legislative authority should rest with voters than those who think it should rest with the Parliament (54.9\% versus $24.7 \%$ ). The other effects are somewhat smaller in size. Candidates who hold negative perceptions of MPs are $14.2 \%$ more likely to expect MPs to prioritise their voters' views than candidates who think positively of MPs (38\% versus 22.2\%), while candidates who are most satisfied with the state of democracy in the UK are $11.9 \%$ more likely to believe that MPs ought to prioritise their voters' views than candidates who are least satisfied with it ( $41.9 \%$ versus $30 \%$ ). It is important to note, however, that there is overlap in the 95\% confidence intervals for the latter. Candidates' attitude towards representation is shaped by their political and personal profile, as well as their political views.

\section{[TABLE 4 HERE]}

\section{Is there any evidence of a Brexit effect?}

There are 197 candidates whose views on how they believe MPs should vote when facing the dilemma between following their own judgement or their voters' preferences are known before and after the EU referendum. We also know both for candidates who ran for the same party in the same constituency in 295 instances. $^{9}$ Taken together, they provide further insight into whether there really was no Brexit

\footnotetext{
${ }^{9}$ In other words, we know the pre-referendum and post-referendum views of party $\mathrm{X}$ candidate in constituency $\mathrm{Y}$. The comparison would be between the views of the same candidate if party $\mathrm{X}$ fielded the same candidate in constituency Y in 2015 and 2017. However, if party X put forward different candidates in constituency Y at the 2015 and 2017 general elections, the comparison would be between the view of the 2015 candidate and the view of the 2017 candidate.
} 
effect in how politicians think about this question of parliamentary representation. ${ }^{10}$ Table 5 presents both comparisons.

The comparison of candidates' beliefs on whether MPs should prioritise the views of their voters over those of their own, or vice versa, before and after the EU referendum does not reveal any fundamental change in how candidates think about parliamentary representation. Most candidates - 148 out of 197 $(75.1 \%)$ - were unchanged in their belief of whose views should MPs prioritise. The most common option was for candidates to think before as well as after the EU referendum that MPs should prioritise their own views, applying to 120 of them. Only around one-in-four (49 out of 197) changed their mind. Interestingly, while one might have expected the more popular switch to be from expecting MPs to prioritise their own views to expecting MPs to prioritise their voters' views in light of the 'out of touch' narrative that has dominated much of the public discourse after the EU referendum, this was not the case. Of the 49 candidates who changed their mind, only 21 switched from expecting MPs to prioritise their own views to expecting them to prioritise those of their voters, while 28 candidates moved from a voter-centred perception of behaviour to an MP-centred one. We do not find evidence that the Brexit vote had a strong effect on how politicians think about parliamentary representation.

The picture is broadly similar when comparing the views of candidates whom parties picked to run for them in the same constituency at the 2015 and 2017 general elections. The most common combination here is also for a party's 2015 and 2017 general election candidates in a given constituency to both say that MPs should prioritise their own views over those of their voters, applying to 154 (52.2\%) cases. There are more instances of parties picking candidates with different views to run for them in 2015 and 2017 than the proportion of individual candidates who changed their mind, as one would expect, but they still constitute only a minority of 108 (36.6\%) cases. These instances split almost perfectly between own-to-voters and voters-to-own scenarios (52 versus 56 ). Taken together, it does not appear that the Brexit vote, and the following attention on the question of how MPs should vote when their view differs from that held by the majority of their voters, has fundamentally altered how politicians think about this key aspect of parliamentary representation.

[TABLE 5 HERE]

\section{Conclusion}

\footnotetext{
${ }^{10}$ It is important to interpret these comparisons with some caution as the sample sizes are relatively low. There is not enough data to undertake an extended analysis of which characteristics influence whether candidates changed their view of parliamentary representation or not, but these data, nonetheless, offer valuable first-cut insight, even if descriptive, into how (un)common it was for individual candidates to change their view and constituency parties to choose candidates with contrasting views.
} 
The 2016 EU referendum exposed profound divisions in the British political system and society more broadly. We witnessed the electorate split almost perfectly between Leave and Remain as well as very public disagreements among politicians and political parties. What we also saw in the aftermath of the referendum, however, was growing debate around issues of parliamentary representation and the role of legislators. In particular, the question of whether MPs should prioritise their own judgement or the preferences of their voters rose to the forefront of public discourse. While we have a good account of how voters believe MPs should act when facing such a dilemma, evidence from the elite side is scarcer.

This study utilises data from the Representative Audit of Britain Study to address this lacuna. It explores whether candidates believe MPs should prioritise their own judgement or their voters' views, how different individual-level factors shape their perception of MPs' role, and whether there was a Brexit effect in how politicians think about this issue of representation. We find that most candidates expect MPs to prioritise their own judgment over their voters' preferences, by a ratio of around 2:1. In addition, we find that this perception is particularly common among incumbents and those who do not think of MPs as career politicians, and that male candidates are more likely to suggest that MPs should prioritise their own opinion over their voters' views than their female counterparts. We do not, however, find a Brexit effect when comparing the views of 2015 and 2017 general election candidates.

There are three broader points arising from this study. First, the findings suggest that attitudes towards parliamentary representation are relatively stable among politicians. While we do find some variation in how candidates see the role of MPs, there is very little evidence of over-time change. The $2016 \mathrm{EU}$ referendum was one of the most important political events in the UK in recent times. It set into motion developments that are still shaping its political landscape and, among else, pushed into new-found prominence the question of whether MPs should prioritise their own judgement or their voters' views when the two are not aligned. It became clear that most voters wanted MPs to prioritise their constituents' opinions. Despite the strength and public nature of this sentiment, the views of politicians, however, remained largely unaffected. The 2015 and 2017 general election candidates perceived the role of MPs in very similar terms, while those who did change their view between 2015 and 2017 were more likely to move in the 'wrong direction' from the public's perspective. Politicians' views towards parliamentary representation are very stable and do not appear to be significantly influenced by external events, even those as prominent as the EU referendum.

Second, the findings shown here lend further support to the prominent narrative in British politics that politicians are 'out of touch' with voters. The EU referendum highlighted very publicly the disconnect between politicians and the public on a key policy question. This disconnect, however, extends further than a difference of opinion regarding Leaving and Remaining. It is also present when comparing how voters and politicians see the role of MPs. While most politicians want MPs to prioritise their opinions 
over those of their voters, most voters think the opposite ought to be the case. This difference of views in how MPs should act is particularly prominent when comparing what voters and political elites - i.e., those who have been MPs - think. Taken against the backdrop of general mistrust that a lot of voters in Britain have towards politicians, these findings cast further doubt on the possibility of any 'quick fixes' to the relationship between voters and politicians. To the extent that political discontent is driven by the perception of politicians being 'out of touch', these narratives are unlikely to be changed by political elites becoming more attuned to promoting their voters' preferences over their own.

There is an important caveat though to the relatively pessimistic outlook touched upon above. We find a strong and highly significant gender effect as female candidates are much more likely to think about MPs as representatives of their voters' views, even if that entails discarding their own judgement, than male candidates. While there are still more male MPs than female MPs in the UK, it does appear that this imbalance is slowly declining, with the 2019 election returning the highest number and proportion of female MPs ever (House of Commons Library 2020). Should Parliament continue to become more gender balanced in its make-up, so too should it naturally include more MPs who are willing to follow their voters' preferences over their own judgement, as most voters expect them to. This would provide a positive contribution to the voters-elite relationship, but it also suggests that the Parliament changing its perception of what it entails to be an elected representative is more likely to arise from changing the MPs, rather than MPs themselves changing their views on the matter.

In sum, these findings broaden our understanding of how MPs are expected to approach parliamentary representation. They build on the already extensive body of evidence from the voter side and examine what would-be MPs believe MPs ought to do when facing a voting dilemma between prioritising their own judgement or their voters' opinion. In doing so, these findings not only extend our understanding of how the 'political class' perceives the role of legislators, but they also allow for comparisons between would-be MPs and across time. At the same time, this study highlights the need for extending this line of enquiry. Future research should extend the range of explanatory variables used and the timeframe it focuses on. It should also examine how MPs are expected to carry out their parliamentary duties when they are facing different kinds of voting dilemmas. 


\section{Appendix A. The Representative Audit of Britain Survey}

The Representative Audit of Britain Survey provides unique data to study the attitudes of parliamentary candidates in Britain. It provides information on all variables of interest for this study for 500 candidates who ran at the 2017 general election and 642 candidates who ran at the 2015 general election in Britain. We use the Duncan index of dissimilarity to evaluate the representativeness of these samples. The index ranges from 0 to 1 , with higher values meaning greater discrepancy between the full population and the sample (Duncan and Duncan 1955).

Table A1 shows the comparison between the sample used and the full population of candidates on three characteristics - party, nation, and electoral performance. The comparison of partisanship yields values of 0.18 for 2015 and 0.24 for 2017, while nation yields values of 0.02 for 2015 and 0.04 , and electoral performance shows scores of 0.12 for 2015 and 0.15 for 2017. While the 2015 and 2017 samples remain broadly representative of the respective populations of candidates, there are some differences that need highlighting, as one would expect when the data derive from elite surveys. The data used in the analyses under-represent successful candidates and those running under the Conservative Party banner. This is a limitation of the analysis and does call for a degree of caution when interpreting the findings. That said, the data still provide unique insight into the attitudes of a broad, and relatively representative, range of parliamentary candidates, including some who stood at both the 2015 and 2017 general elections.

Table A1. The Representative Audit of Britain Survey sample

\begin{tabular}{lcccc}
\hline & \multicolumn{2}{c}{2017} & & 2015 \\
& Candidates $(\%)$ & Sample $(\%)$ & Candidates $(\%)$ & Sample $(\%)$ \\
\hline Party & & & & \\
Conservative Party & 22.3 & 1.8 & 19.9 & 7.5 \\
Green Party & 16.3 & 26.2 & 17.9 & 26.2 \\
Labour Party & 22.3 & 26.2 & 19.9 & 19.2 \\
Liberal Democrats & 22.2 & 32.4 & 19.9 & 29.6 \\
Nationalist parties & 3.5 & 3.0 & 3.1 & 3.1 \\
Ukip & 13.4 & 10.4 & 19.3 & 14.5 \\
& Duncan index $=0.24$ & Duncan index $=0.18$ \\
Nation & & & 82.9 & 85.4 \\
England & 84.1 & 87.8 & 9.7 & 7.8 \\
Scotland & 8.8 & 6.0 & 7.4 & 6.9 \\
Wales & 7.1 & 6.2 & Duncan index $=0.02$ \\
& Duncan index $=0.04$ & & 8.3 \\
Electoral performance & & & 19.9 & 91.7 \\
Successful & 22.3 & 7.4 & Duncan index $=0.12$ \\
Unsuccessful & 77.7 & 92.6 & & \\
& Duncan index $=0.15$ & & \\
\hline
\end{tabular}




\section{Appendix B. Robustness check for empirical strategy}

Table B1 presents findings from the models that include only candidates who stood at the 2017 general election (Model B1) or the 2015 general election (Model B2).

Table B1. Explaining variation in role perception, by year

\begin{tabular}{lcc}
\hline & \multicolumn{2}{c}{ Priority (voters v. self) } \\
& Model B1: 2017 & Model B2: 2015 \\
\hline Incumbency & $-1.07^{*}(0.51)$ & $-1.64^{*}(0.76)$ \\
MP assistant & $-0.58(0.53)$ & $-0.56(0.44)$ \\
Perception of MPs & $0.36^{* *}(0.12)$ & $0.12(0.10)$ \\
Final decision & $-0.56^{* *}(0.12)$ & $-0.22^{*}(0.09)$ \\
Satisfaction with democracy & $0.55^{* *}(0.17)$ & $-0.03(0.13)$ \\
Locality & $0.31(0.23)$ & $0.23(0.20)$ \\
EU alignment & $0.26(0.23)$ & $0.09(0.19)$ \\
Gender & $0.74^{* *}(0.23)$ & $0.97 * *(0.21)$ \\
Age & $-0.01(0.01)$ & $-0.01(0.01)$ \\
Party^ & & \\
$\quad$ Labour Party & $-0.23(0.78)$ & $-0.58(0.47)$ \\
$\quad$ Liberal Democrats & $-0.93(0.81)$ & $-0.14(0.45)$ \\
$\quad$ Green Party & $-0.37(0.83)$ & $0.27(0.49)$ \\
$\quad$ Ukip & $0.18(0.88)$ & $1.21^{*}(0.51)$ \\
$\quad$ Nationalist parties & $0.55(0.98)$ & $-0.39(0.70)$ \\
Constant & $-1.16(1.26)$ & $-1.22(0.88)$ \\
Observations & 500 & 642 \\
Log likelihood & -263 & -358 \\
\hline
\end{tabular}

Note: standard errors in parentheses; ${ }^{*} \mathrm{p}<0.05,{ }^{*} \mathrm{p}<0.01$.

^ Reference category is 'Conservative Party'.

$\wedge^{\wedge}$ Reference category is ' 2015 '. 


\section{References}

Adler, S.E., Cayton, A.F. and Griffin, J.D. 2018. Representation When Constituent Opinion and District Conditions Collide. Political Research Quarterly 71/3: 681-694.

Albarracín, J., Wang, W. and Albarracín, D. 2012. Are Confident Partisans Disloyal? The Role of Defensive Confidence in Party Defection. Journal of Applied Social Psychology 42/7: 15761598.

Andeweg, R.B. and Thomassen, J.J.A. 2005. Modes of Political Representation: Toward a New Typology. Legislative Studies Quarterly 30/4: 507-528.

Barker, D.C. and Carman, C.J. 2012. Representing Red and Blue: How the Culture Wars Change the Way Citizens Speak and Politicians Listen. Oxford: Oxford University Press.

Baughman, J. 2004. Party, Constituency, and Representation: Votes on Abortion in the British House of Commons. Public Policy 150/1-2: 63-85.

BBC. 2015. Election 2015: UKIP Manifesto at-a-glance. Available online at: https://www.bbc.co.uk/news/election-2015-32318683.

BBC. 2017. UKIP Manifesto Summary: Key Points at-a-glance. Available online at: https://www.bbc.co.uk/news/election-2017-40042669.

Buzzfeed. 2017. More than 120 MPs voted against their constituencies on Brexit. Available online at: https://www.buzzfeed.com/marieleconte/more-than-120-mps-voted-against-theirconstituencies-on-brex.

Campbell, R. and Cowley, P. 2014. Rebellion Versus Loyalty, Shirking Versus Working: A Note on Framing Parliamentary Behaviour. Representation 50/4: 421-427.

Campbell, R., Cowley, P., Vivyan, N. and Wagner, M. 2019. Why Friends and Neighbors? Explaining the Electoral Appeal of Local Roots. The Journal of Politics 81/3: 937-951.

Campbell, R., van Heerde-Hudson, J. and Rüdig, W. 2017. The Representative Audit of Britain Survey ESRC - ES/L016508/1, 2015, 2017.

Campbell, R. and Lovenduski, J. 2015. What Should MPs Do? Public and Parliamentarians' Views Compared. Parliamentary Affairs 68/4: 690-708.

Carman, C.J. 2006. Public Preferences for Parliamentary Representation in the UK: An Overlooked Link? Political Studies 54/1: 103-122.

CCS. 2020. Comparative Candidates Survey Wave II - 2013-2019 [Dataset - Cumulative File]. Distributed by FORS, Lausanne. Available online at: https://doi.org/10.23662/FORS-DS-886-4.

Clarke, N., Jennings, W., Moss, J. and Stoker, G. 2018. The Good Politician: Folk Theories, Political Interaction, and the Rise of Anti-politics. Cambridge: Cambridge University Press.

Converse, P.E. and Pierce, E. 1986. Political Representation in France. Cambridge: Belknap Press of Harvard University Press.

Cowley, P. 2002. Revolts and Rebellions: Parliamentary Voting Under Blair. London: Politico's. 
Cowley, P. and Stuart, M. 2010. Party Rules, OK: Voting in the House of Commons on the Human Fertilisation and Embryology Bill. Parliamentary Affairs 63/1: 173-181.

Daily Mail. 2017. The Remoaners-in-chief: MPs who defied the will of their constituents by voting against triggering Article 50. Available online at: https://www.dailymail.co.uk/news/article4181134/MPs-DEFIED-constituents-voting-against-Brexit.html.

Deschouwer, K. and Depauw, S. 2014. Representing the People: A Survey among Members of Statewide and Substate Parliaments. Oxford: Oxford University Press.

Doherty, D. 2013. To Whom Do People Think Representatives Should Response: Their District or the Country? Public Opinion Quarterly 77/1: 237-255.

Dudzińska A., Poyet C., Costa, O. and Wessels B. 2014. Representational Roles. In K.Deschouwer and S.Depauw (eds.) Political Representation and Legitimacy in the European Union. Oxford: Oxford University Press, pp.19-38.

Duncan, O.D. and Duncan, B. 1955. A Methodological Analysis of Segregation Indexes. American Sociological Review 20/2: 210-217.

Fieldhouse, E., Green, J., Evans, G., Mellon, J., Prosser C., de Geus, R., Bailey, J., Schmitt, H. and van der Eijk, C. 2020. British Election Study Internet Panel Waves 1-20. Available online at: https://www.britishelectionstudy.com/data-objects/panel-study-data.

Hafner-Burton, E.M., Alex Hughes, D. and Victor, D.G. 2013. The Cognitive Revolution and the Political Psychology of Elite Decision Making. Perspectives on Politics 11/2: 368-386.

Hanretty, C. 2017. Areal Interpolation and the UK's Referendum on EU Membership. Journal of Elections, Public Opinion and Parties 27/4: 466-483.

Heppell, T., Crines, A. and Jeffery, D. 2017. The United Kingdom Referendum on European Union Membership: The Voting of Conservative Parliamentarians. Journal of Common Market Studies 55/4: 762-778.

House of Commons Library. 2020. General Election 2019: How Many Women Were Elected? Available online at: https://commonslibrary.parliament.uk/general-election-2019-how-manywomen-were-elected.

Hughes, C. 2019. It's the EU Immigrants Stupid! UKIP's Core-Issue and Populist Rhetoric on the Road to Brexit. European Journal of Communication 34/3: 248-266.

Ipsos Mori. 2019. Trust in Politicians Falls Sending Them Spiralling Back to the Bottom of the Ipsos MORI Veracity Index. Available online at: https://www.ipsos.com/ipsos-mori/en-uk/trustpoliticians-falls-sending-them-spiralling-back-bottom-ipsos-mori-veracity-index.

Jennings, W., Stoker, G., Devine, D. and Gaskell, J. 2019. Political Trust Realigned After the General Election. The UK in a Changing Europe. Available online at: https://ukandeu.ac.uk/politicaltrust-realigned-after-the-general-election.

Kalaian, H.A. and Freeman, D.J. 1994. Gender Differences in Self-Confidence and Educational Beliefs among Secondary Teacher Candidates. Teaching and Teacher Education 10/6: 647-658. 
Kolpinskaya, E. 2017. Substantive Religious Representation in the UK Parliament: Examining Parliamentary Questions for Written Answers, 1997-2012. Parliamentary Affairs 70/1: 111-131. Lausberg, A.K. 2016. Women and Representation: Cross-Party Collaboration in the Australian Federal Parliament. Parliamentary Affairs 69/2: 249-268.

McKay, L. 2020. Does Constituency Focus Improve Attitudes to MPs? A Test for the UK. The Journal of Legislative Studies 26/1: 1-26.

Press Association. 2016. How MPs Voted in the EU Referendum. Available online at: http://home.bt.com/news/uk-news/how-mps-voted-in-the-eu-referendum-11364110245462.

Russell., M. 2019. Why a Rhetoric of 'Parliament versus People' is both Dishonest and Dangerous. The UK in a Changing Europe. Available online at: https://ukandeu.ac.uk/why-a-rhetoric-ofparliament-versus-people-is-both-dishonest-and-dangerous.

Saalfeld, T. 2011. Parliamentary Questions as Instruments of Substantive Representation: Visible Minorities in the UK House of Commons, 2005-10. The Journal of Legislative Studies 17/3: 271289.

Searing, D. 1994. Westminster's World: Understanding Political Roles. London: Harvard University Press.

Slapin, J.B., Kirkland, J.H., Lazzaro, J.A., Leslie, P.A. and O’Grady, T. 2018. Ideology, Grandstanding, and Strategic Party Disloyalty in the British Parliament. American Political Science Review, 112/1: 15-30.

Stafford, C. 2020. Brexit: How MPs Struggled to Reflect their Voters. Available online at: https://www.psa.ac.uk/psa/news/brexit-how-mps-struggled-reflect-their-voters.

Stanyer, J., Archetti, C. and Sorensen, L. 2017. The United Kingdom. Hybrid Populisms, Mixed Fortunes and Unstable Support. In T.Aalberg, F.Esser and C.Reinemann (eds.) Populist Political Communication in Europe. New York: Routledge, pp. 165-180.

Sudulich, L., Trumm, S. and Bridgewater, J. 2020. Parliamentary Representation: A Cross-National Study of Candidates' Views. Parliamentary Affairs 73/3: 522-542.

The Sun. 2019. The Brexit wreckers: MPs who are betraying their constituents by trying to thwart Brexit. Available online at: https://www.thesun.co.uk/news/brexit/8548383/brexit-mps-ignoringleave-voting-constituents.

Vasilopoulou, S. 2020. Brexit and the 2019 EP Election in the UK. Journal of Common Market Studies. OnlineFirst.

Wagner, M., Vivyan, N. and Glinitzer, K. 2020. Costly Signals: Voter Responses to Parliamentary Dissent in Austria, Britain, and Germany. Legislative Studies Quarterly. OnlineFirst.

Watts, J. and Bale, T. 2019. Populism as an Intra-Party Phenomenon: The British Labour Party under Jeremy Corbyn. The British Journal of Politics and International Relations 21/2: 99-115. 
Wessels, B. and Giebler, H. 2010. Focus and Style-An Old Debate Revived. Available online at: https://www.researchgate.net/publication/228198206_Focus_and_Style__An_Old_Debate_Revived.

Zmerli, S. and Newton, K. 2017. Objects of Political Trust: Scales and Hierarchies. In S.Zmerli and T. van der Meer (eds.) Handbook on Political Trust. Cheltenham: Edward Elgar, pp.104-124. 


\section{Tables}

Table 1. Expectations

\begin{tabular}{|c|c|}
\hline Hypothesis & Effect \\
\hline $\mathrm{H}_{1}$ : Incumbents are less likely to expect MPs to prioritise their voters' views & - \\
\hline $\begin{array}{l}\mathrm{H}_{2} \text { : Candidates who have worked as MP assistants are less likely to expect MPs to } \\
\text { prioritise their voters' views }\end{array}$ & - \\
\hline $\begin{array}{l}\mathrm{H}_{3} \text { : Candidates with a more negative perception of MPs are more likely to expect MPs } \\
\text { to prioritise their voters' views }\end{array}$ & + \\
\hline $\begin{array}{l}\mathrm{H}_{4} \text { : Candidates with a more Parliament-centric view of the legislative process are less } \\
\text { likely to expect MPs to prioritise their voters' views }\end{array}$ & - \\
\hline $\begin{array}{l}\mathrm{H}_{5} \text { : Candidates who are more satisfied with the state of democracy in the United } \\
\text { Kingdom are more likely to expect MPs to prioritise their voters' views }\end{array}$ & + \\
\hline $\begin{array}{l}\mathrm{H}_{6} \text { : Candidates living in the constituency are more likely to expect MPs to prioritise } \\
\text { their voters' views }\end{array}$ & + \\
\hline $\begin{array}{l}\mathrm{H}_{7} \text { : Candidates whose EU referendum vote choice aligned with the constituency are } \\
\text { more likely to expect MPs to prioritise their voters' views }\end{array}$ & + \\
\hline $\mathrm{H}_{8}$ : Female candidates are more likely to expect MPs to prioritise their voters' views & + \\
\hline $\mathrm{H}_{9}$ : Older candidates are less likely to expect MPs to prioritise their voters' views & - \\
\hline $\mathrm{H}_{10}: 2017$ candidates are more likely to expect MPs to prioritise their voters' views & + \\
\hline
\end{tabular}


Table 2. Overview of role perception

\begin{tabular}{lrrr}
\hline & & Own (\%) & Voters (\%) \\
\hline Year & 2017 & 66.7 & 33.3 \\
& 2015 & 65.8 & 34.2 \\
Party & & \\
& Conservatives & 78.7 & 21.3 \\
& Labour Party & 72.4 & 27.6 \\
& Liberal Democrats & 74.0 & 26.0 \\
& Green Party & 61.0 & 39.0 \\
& UKIP & 39.8 & 60.2 \\
& National parties & 68.1 & 31.9 \\
\hline All candidates & 66.2 & 33.8 \\
\hline
\end{tabular}


Table 3. Explaining variation in role perception

\begin{tabular}{lc}
\hline & Prioritise voters \\
\hline Incumbency & $-0.94^{*}(0.38)$ \\
MP assistant & $-0.47(0.33)$ \\
Perception of MPs & $0.22^{* *}(0.07)$ \\
Final decision & $-0.36^{* *}(0.07)$ \\
Satisfaction with democracy & $0.21^{*}(0.10)$ \\
Locality & $0.22(0.15)$ \\
EU alignment & $0.15(0.14)$ \\
Gender & $0.86^{* *}(0.15)$ \\
Age & $-0.01(0.01)$ \\
Party^ & \\
$\quad$ Labour Party & $-0.02(0.38)$ \\
$\quad$ Liberal Democrats & $-0.21(0.39)$ \\
$\quad$ Green Party & $0.27(0.41)$ \\
$\quad$ Ukip & $1.18^{* *}(0.43)$ \\
$\quad$ Nationalist parties & $0.25(0.53)$ \\
Year^^ & \\
$\quad$ 2017 & $0.19(0.14)$ \\
Constant & $-1.56^{*}(0.70)$ \\
Observations & 1,142 \\
Log likelihood & -638 \\
\hline Note: standard errors in parentheses; *p<0.05, **p<0.01. & \\
$\wedge$ Reference category is 'Conservative Party'. & \\
$\wedge \wedge$ Reference category is '2015'. &
\end{tabular}


Table 4. Predicted likelihood of prioritising voters

\begin{tabular}{cc}
\hline & Prioritise voters $(\%)$ \\
\hline Incumbency & $34.3(31.7-37.0)$ \\
Challenger & $18.8(9.0-28.5)$ \\
Incumbent & 15.5 \\
$\Delta$ & \\
Perception of MPs & $22.2(15.1-29.2)$ \\
Most positive & $38.0(33.9-42.1)$ \\
Most negative & 14.2 \\
$\Delta$ & $54.9(46.1-63.7)$ \\
Final decision & $24.7(20.9-28.5)$ \\
Voters & 30.5 \\
Parliament & \\
$\Delta$ & $30.0(26.1-34.0)$ \\
Satisfaction with democracy & $41.9(33.2-50.7)$ \\
Not at all satisfied & 11.9 \\
Very satisfied & \\
$\Delta$ & $28.6(25.7-31.5)$ \\
Gender & $46.0(40.6-50.8)$ \\
Male & 17.4 \\
Female &
\end{tabular}

Note: $95 \%$ confidence intervals in parentheses. 
Table 5. Role perceptions in 2015 and 2017

\begin{tabular}{lcc}
\hline & & Candidates \\
\hline Unchanged & Own->Own & 120 \\
& Voters->Voters & 28 \\
Changed & & \\
& Own->Voters & 21 \\
& Voters->Own & 28 \\
\hline Unchanged & & Parties* \\
& Own->Own & 154 \\
Changed & Voters->Voters & 33 \\
& & \\
& Own->Voters & 52 \\
& Voters-> Own & 56 \\
\hline
\end{tabular}

* Note: party candidate in the same constituency. 